Research Report No. 6/2009

\title{
The Evolution of the Corporation: Organization, Finance, Knowledge and Corporate Social Responsibility
}

Peer Zumbansen

Osgoode Hall Law School of York University, PZumbansen@osgoode.yorku.ca

Follow this and additional works at: http://digitalcommons.osgoode.yorku.ca/clpe

\section{Recommended Citation}

Zumbansen, Peer, "The Evolution of the Corporation: Organization, Finance, Knowledge and Corporate Social Responsibility" (2009). Comparative Research in Law \& Political Economy. Research Paper No. 6/2009.

http://digitalcommons.osgoode.yorku.ca/clpe/121 


\section{Comparative Research in Law \& Political Economy}

\section{Peer Zumbansen}

The Evolution of The Corporation: Organization, Finance, Knowledge And Corporate Social Responsibility

EDITORS: Peer Zumbansen (Osgoode Hall Law School, Toronto, Director, Comparative Research in Law and Political Economy, York University), J ohn W. Cioffi (University of California at Riverside), Lindsay Krauss (Osgoode Hall Law School, Toronto, Production Editor) 

CLPE Research Paper 06/2009

Vol. 05 No. 01 (2009)

\title{
Peer Zumbansen
}

\section{THE EVOLUTION OF THE CORPORATION: ORgANIZATION, FinANCE, KNOWLEDGE AND CORPORATE SOCIAL RESPONSIBILITY}

\begin{abstract}
This paper, which selectively focuses on the contested concept of Corporate Social Responsibility [CSR], forms part of a larger research project on the evolution of corporate governance. This research posits the evolution of corporate governance along three historical paradigms: first, the economic/industrial organization paradigm, second, the financial paradigm, and third, the knowledge paradigm. With regard to CSR, the paper explores the promises and shortcomings of the concept against the background of an evolutionary theory of corporate governance. The identification of three historical-conceptual paradigms allows us to trace the development of the relation between a general discourse on corporate governance regulation [CGR] on the one hand and a more specialized, often polemic debate over corporate (social, environmental, human rights) responsibilities on the other. On the basis of the review of the three paradigms of CSR over the course of more than one hundred years, the paper concludes that there is no convincing justification to separate the general Corporate Governance from the more specific CSR discourse when assessing the nature of the corporation. Instead, it is argued that a more adequate understanding of what defines a corporation is gained when capturing its embedded nature in a continuously changing domestic, global and functional environment. Besides being both a legal fiction and an economic actor, the business corporation is assuming a host of other roles in a functionally differentiated global society. The paper suggests that the generation and dissemination of knowledge, both internally and externally, has become the defining feature of the firm. The corporation as a knowledge actor succeeds the prior stages of assessing it as a private, political or financial actor, without however erasing these dimensions of the firm. In that, the history of the corporation - as concept and reality shares important features with that of the state - as concept and as fact.
\end{abstract}


Keywords: corporate social responsibility, corporate governance, financialisation, economic sociology, knowledge society, uncertainty, risk, management

JEL classification: G38, K22

\author{
Author Contact: \\ Peer Zumbansen \\ Canada Research Chair in the Transnational and Comparative Law \\ of Corporate Governance \\ Osgoode Hall Law School, York University, Toronto. \\ Director, Critical Research Laboratory in Law \& Society \\ www.criticalresearchlab.org \\ Email: Pzumbansen@osgoode.yorku.ca
}

\title{
Acknowledgements
}

Paper prepared for the Annual Conference of the International Bar Association, Buenos Aires 12-17 October 2008. Earlier versions of this research were presented at the Conference of the European Association of Evolutionary Political Economy, Paris 22-23 May 2008 and at the Third Annual Conference “The Embedded Firm”, of the CLPE Comparative Research in Law \& Political Economy Network at Osgoode Hall Law School, Toronto, 20-21 March 2008.

Further information about the Centre for Business Research and about CLPE can be found at the following websites: www.cbr.cam.ac.uk and www.comparativeresearch.net

CLPE Comparative Research in Law \& Political Economy Network Research Paper 6/2009

$\&$

Centre for Business Research, University of Cambridge

Working Paper No. 373 
February 2009

This working paper forms part of the CBR Research Programme on Corporate Governance at the University of Cambridge Centre for Business Research and of the CLPE Comparative Research in Law \& Political Economy Network at Osgoode Hall Law School, York University, Toronto. 



\title{
THE EVOLUTION OF THE CORPORATION: ORGANIZATION, FINANCE, KNOWLEDGE AND CORPORATE SOCIAL RESPONSIBILITY
}

\author{
Peer Zumbansen ${ }^{*}$
}

\section{INTRODUCTION}

Reflections on Corporate Social Responsibility [CSR] in the midst of a large financial crisis are likely to have several starting and turning points. The current twists and turns of the financial markets dramatically put into perspective the religious wars fought over the last 20 years between shareholder value proponents and stakeholder capitalism defenders, carried out as a dispute over global convergence or divergence of corporate governance standards. The unprecedented expansion of global corporate finance ${ }^{1}$ - most accentuated since the collapse of Communism dramatically changed our entire perspective on the business corporation as it had been conceived both at the beginning of the century as well as during the aftermath of WW II in Western industrialized nations. This

\footnotetext{
* This paper forms part of a larger research project on corporate governance in the knowledge society. Parts of this research were presented at the March 2008 CLPE Conference in Toronto on "The Embedded Firm", the May 2008 Conference of the European Association of Evolutionary Political Economy in Paris, the Faculty Seminar at Tel Aviv University Buchmann Faculty of Law on 17 June 2008 and at the International Bar Association Conference on 14 October in Buenos Aires, Argentina. I owe sincere thanks for helpful feedback and comments to Yuri Biondi, Antoine Rébérioux, Shyam Sunder, Roy Kreitner, Jan Eijsbouts, Fenner Stewart, Phillip Bevans, Cynthia Williams, Ed Waitzer, Steven Diamond, Simon Deakin, Simon Archer, Aaron Dhir, Gil Lan and Amar Bhatia. Financial Assistance from the Social Sciences and Humanities Research Council of Canada (Grant \# 410-2005-2421) and from the IBA is gratefully acknowledged.
}

${ }^{1}$ S. Jacoby, 'Finance and Labor: Perspectives on Risk, Inequality and Democracy', (2008) SSRN Working Paper, available at http://ssrn.com/abstract=1020843 (in P. Zumbansen \& C.Williams eds., The Embedded Firm: Labour, Corporate Governance, and Finance Capitalism, 2009) forthcoming, at 2; R. Dore, 'Financialization of the Global Economy', (2008) 17 Industrial and Corporate Change 1097-1112 
change in perspective from industrial, embedded capitalism to financial capitalism tells a story about the way in which we attribute different categories of responsibilities to the business corporation. While we are seemingly well acquainted with the 'classical' segments of that story ${ }^{2}$, its continuation is anything but clear. The history of corporate social responsibility as an ideal, concept, dream, ideology, or illusion is as intertwined in the larger political economy of capitalist development ${ }^{3}$ as it has a particular idiosyncratic history of its own. ${ }^{4}$ The following observations aim at illustrating this history. In search of adequate landmarks or milestones of this history, we find, on the one hand an overwhelming amount of conflicting contestations, viewpoints and programs. On the other, we find a much smaller number of greater frameworks, which seem to have provided a space of reference for a continuing negotiation of what can actually be meant by CSR.

Such frameworks or, paradigms, provide the conceptual foundation on which a field is constituted - over a particular period of time, in a particular space, under particular circumstances. A paradigm is exhausted if the field produces 'anomalies' which cannot be explained with reference to the hitherto reigning paradigm. ${ }^{5}$ This paper proposes to reflect on the history and on the prospects - of CSR through the study of its evolution by focusing on three larger paradigms. I will introduce these three paradigms as lenses through which we can perhaps better understand the neverending quarrel about CSR after a short setting of the stage. The organizational-industrial paradigm of the Corporation, which in turn

2 See e.g. L. Wedderburn of Charlton, 'The Legal Development of Corporate Responsiblity: For Whom Will Corporate Managers Be Trustees?' in K. J. Hopt and G. Teubner (eds.), Corporate Governance and Directors' Liabilities: Legal, Economic and Sociological Analyses on Corporate Social Responsibility (Walter de Gruyter, 1985).

3 E. Latham, 'The Body Politic of the Corporation', in E. S. Mason (eds.), The Corporation in Modern Society (Harvard University Press, 1961): "The great corporations are political systems in which their market, social, and political influence go far beyond their functional efficiency in the economy.” Id., at 218

${ }^{4}$ J. H. van Oosterhout/P. P. M. A. R. Heugens, 'Much Ado about Nothing: A Conceptual Critique of Corporate Social Responsibility', in A. Crane,A. McWilliams,D. Matten,J. Moon and D. S. Siegel (eds.), Oxford Handbook of Corporate Social Responsibility (Oxford University Press, 2008)

${ }^{5}$ T. S. Kuhn, The Structure of Scientific Revolutions (University of Chicago Press, 1962) 
informs our understanding of CSR in this context and evolved over the first 75 years of the twentieth century with tremendous conceptual capacities, views the corporation as a battle-field of differing concepts of market intervention on the one hand and of the conflict over the appropriate role of business enterprises and the scope of legal regulation of business in the context of Keynesian economics and Welfare statism, on the other. Within the first paradigm, the relevance of contested 'social responsibilities' of the business corporation can only be understood when seen against the larger background of a radically unfolding market economy $^{6}$, a critique of formal law ${ }^{7}$ and a deep-reaching deconstruction of political, legal and economic power. ${ }^{8}$ For corporate law, this phase is marked by heated normative debates over the social status of business corporations. These contestations can only be appreciated fully when seen in a still larger context of social theory. The rise of the interventionist state in France and Germany, the full-blown turn to instrumentalize law as a tool of social engineering during the U.S. New Deal and the widespread emergence of an ambitious regulatory state apparatus in Western democracies ${ }^{9}$ provides the context for the ideological fight over the public or private nature of the corporation.

This period of the 'social' is succeeded, within legal and social theory, by an amalgamation of competing assessments of the social structure. ${ }^{10}$ In the comparably confined field of corporate theory, the second, financial paradigm of the corporation shifts the focus from management's balancing of competing societal interests towards a fundamental transformation of the corporation into an investment vehicle whose success is measured almost exclusively with reference to its returns to stockholders. In a

\footnotetext{
${ }^{6}$ K. Polanyi, The Great Transformation. The Political and Economic Origins of our Time (Beacon Press, 1944)

${ }^{7}$ O. W. J. Holmes, 'The Path of the Law', (1897) 10 Harv. L. Rev. 457

${ }^{8}$ R. L. Hale, 'Coercion and Distribution in a Supposedly Non-Coercive State', (1923) 38 Political Science Quarterly 470-494; J. P. Dawson, 'Economic Duress - An Essay in Perspective', (1947) 45 Mich. L. Rev. 253-290

${ }^{9}$ D. T. Rodgers, Atlantic Crossings. Social Politics in a Progressive Age (Belknap Harvard, 1998);

${ }^{10}$ D. Kennedy, 'Two Globalizations of Law and Legal Thought: 1850-1968', (2003) 36 Suffolk L. Rev. 631-679
} 
context, which was until recently marked by the wide availability of finance on a global basis that was accompanied by and in turn fuelled a fierce competition for such funds, the firm had become a vehicle for strategic investment placements, a development increasingly complemented by the relinquishing of its role as an organizational laboratory for market governance contestation. Since 1980, the financialization of the corporation has led to a widely held acceptance of subjecting every element of a business firm to varied processes of securitization $^{11}$, involving a fast proliferating landscape of investment actors. ${ }^{12}$ This strategy, pursued by companies across the world, is pursued to attract a highly diversified investment of global investment pools. Farreaching deregulation with regard to capital control during the 1980s has facilitated an unprecedented flow of capital across national boundaries, allowing for securitizations, often repeatedly, of a large number of assets, including pension claims, real estate and commercial claims. With companies designing corporate strategy primarily with stock performance in mind, shareholder value became the dominating principle in assessing corporate performance, fuelled by a seemingly unstoppable growth in index values. Yet, the pressure brought about by the credit crisis, constantly aggravating since 2005, but globally exploding in mid-late 2008, suggests the transition towards another paradigm.

The first two paradigms are telling of the particular political economy constellations that provided the context for the distinct relationships political regulators were striking between individual freedom on the one hand and the political-legal promotion of the public good on the other. In the center of the first paradigm stood the manager ${ }^{13}$, losing his decisive authority under the second paradigm. Characterizing the financial paradigm, Ronald Dore, writes “In today’s investor capitalism, American managers are less autonomous. They operate under the close surveillance

${ }^{11}$ R. Dore, 'Financialization of the Global Economy', (2008) 17 Industrial and Corporate Change 1097-1112, 1099: "The basic financial innovation on which the pyramid of ever more arcane financial instruments is built is securitization.”

12 F. Partnoy/R. Thomas, 'Gap Filling, Hedge Funds and Financial Innovation', in Y. Fuchita and R. E. Litan (eds.), New Financial Instruments and Institutions. Opportunities and Policy Challenges (Brookings, 2007)

13 A. D. Chandler Jr., The Visible Hand: The Managerial Revolution in American Business (Harvard University Press, 1977) 
of a board of directors who represent exclusively the interests of shareholders and may frequently include a dominant shareholder.”14

The new, emerging knowledge paradigm seems to move even more radically beyond this Polanyian framework of a double movement, at the same time assigning an entirely new role to corporate management. The Knowledge paradigm suggests that a corporation has become such a complex entity that we must combine an inside with an outside view of the firm to adequately assess its functions, performances and responsibilities. ${ }^{15}$ In light of the dramatically changed socio-economic functions of the corporation in an era of transnationalization and privatisation any sustainable trajectory for a corporation's social and other responsibilities must build on an adequate assessment of a corporation's environment. The knowledge paradigm points to a fundamental transformation of what corporate management does ${ }^{16}$ and how the law sanctifies or sanctions its actions. Our interest in the knowledge paradigm as applied to the corporation is motivated by the assumption that, under conditions of the continuing radical transformation of the institutional and normative environment of post-Keynesian economics and post-Welfare state governance, future attention has to be directed to both corporations and the state as emblematic representations of this changing environment.

\footnotetext{
${ }^{14}$ R. Dore, 'Financialization of the Global Economy', (2008) 17 Industrial and Corporate Change 1097-1112, at 1103; see also W. Lazonick/M. O'Sullivan, 'Maximizing Shareholder Value: A New Ideology for Corporate Governance', in W. Lazonick and M. O'Sullivan (eds.), Corporate Governance and Sustainable Prosperity (Palgrave Macmillan, 2002).

${ }^{15}$ S. Davis/J. Botkin, 'The Coming of the Knowledge-Based Business', in D. Neef (eds.), The Knowledge Economy (Butterworth, 1998), highlighting the technological and behavioural drivers of the shift from data to information to knowledge; R. Dore, 'Financialization of the Global Economy', (2008) 17 Industrial and Corporate Change 1097-1112, at 1102, noting "a shift in power from managers whose expertise lies in their intimate knowledge of the operations of the organization they run, to owners and representatives of owners who closely monitor their activity with an eye to maximizing the returns to capital."

16 P. F. Drucker, 'From Capitalism to Knowledge Society', in D. Neef (eds.), The Knowledge Economy (Butterworth, 1998)
} 


\section{THe Death of Contract AND THE Rise of FINANCE}

For almost a century the quest into the nature of the firm had been determined by the negotiation of competing social interests. These were institutionalised along very different patterns in capitalist countries around the world. In Western Europe as well as the U.S. until the 1920s, there was a strongly discernable nexus between industrial expansion and welfare politics, in many cases driven by large corporate actors. Starting with the emergence of the 'Speculation Economy' in the third decade of the twentieth century ${ }^{17}$, the role of finance became increasingly important in the organization and regulation of business corporations. In Western Europe, the consolidation of corporate power saw a lesser degree of corporate capture of government powers. Embedded in a tightly regulated system of company, employment and social welfare law, the business corporation remained the anchor point for an ongoing assessment of private power in a fast unfolding market society. ${ }^{18}$ The negotiation of the status and role of the business corporation formed an integral part of Western political economy's self-inspection.

\section{A. CORPORATIONS AND FINANCE}

For lawyers, in particular in private law, this situation presented a formidable opportunity to reflect on the nature of legal regulation of the market. ${ }^{19}$ The next, obvious step was to understand a critical assessment of the role of law in the context of political market intervention as only one example of a much more fundamental analysis of law as such. Beginning with a critical deconstruction of the legal arguments pertaining to the

${ }^{17}$ L. E. Mitchell, The Speculation Economy. How Finance Triumphed over Industry (Berrett-Koehler Publishers, 2007)

${ }^{18}$ F. Böhm, 'Das Problem der privaten Macht', in F. Böhm (eds.), Reden und Schriften (C.F.Müller, 1960)

${ }^{19}$ R. Wiethölter, 'Artikel Bürgerliches Recht', in A. Görlitz (eds.), Handlexikon zur Rechtswissenschaft (Wissenschaftliche Buchgesellschaft, 1972); P. Behrens, Die ökonomischen Grundlagen des Rechts (Mohr Siebeck, 1986) 
autonomy of the firm ${ }^{20}$ to the continuing dispute over a corporation's ownership and control questions ${ }^{21}$, sociologists of law suggested a radical examination of the relation between law and facts, law and social reality. ${ }^{22}$ In this rich context, the business corporation first became subject of intensive legal analysis and social theory critique. ${ }^{23}$ In light of the fastevolving and expanding market society at the turn of the century, the legal imagination of corporate organization was distinctly political. Eventually, with the 'prairie fire' of law \& economics ${ }^{24}$, spreading in the late 1960 s to revive Ronald Coase's theorem of the firm's economic primacy over market contracting ${ }^{25}$, the business corporation seemed to recede again into the amorphous, purportedly apolitical realm of the market, itself conceived as a sphere of private agreement, rational profit seeking and economic efficiency. In historiographical perspective, the life of the corporation as a public, political actor ${ }^{26}$, was of short duration.

Of equally confined nature was the time-horizon against which we subsequently learned to measure the success of a firm: with stock

${ }^{20}$ J. Dewey, 'The Historic Background of Corporate Legal Personality', (1926) 35 Yale L. J. 655-673

${ }^{21}$ A. A. Berle, 'Corporate Powers as Powers in Trust', (1931) 44 Harvard Law Review 1049-1074; E. M. Dodd, 'For Whom are Corporate Managers Trustees?' (1931) 45 Harvard Law Review 1145-1163; A. A. Berle, 'For Whom Corporate Managers are Trustees', (1931) 45 Harvard Law Review 1365-1372; J. Parkinson/G. Kelly/A. Gamble (eds.), The Political Economy of the Company (Hart Publishing, 2000)

22 E. Ehrlich, Fundamental Principles of the Sociology of Law (orig. published in German as Grundlegung der Soziologie des Rechts, 1913) (Russell \& Russell, 1962), 495; G. Gurvitch, Sociology of Law (orig. published in French as Problèmes de la sociologie du droit) (Routledge and Kegan Paul, 1947)

${ }^{23}$ J. Dewey, 'The Historic Background of Corporate Legal Personality', (1926) 35 Yale L. J. 655-673; D. Sciulli, Corporations vs. the Court: Private Power, Public Interests (Lynne Rienner Publishers, 1999)

${ }^{24}$ B. R. Cheffins, 'The Trajectory of (Corporate) Law Scholarship', (2004) 63 Cambr. L. J. 456-506

${ }^{25}$ R. Coase, 'The Nature of the Firm', (1937) 4 Economica 386-405

${ }^{26}$ See only E. S. Mason, 'Introduction', in E. S. Mason (eds.), The Corporation in Modern Society (Harvard University Press, 1961); A. A. Berle, The 20th Century Capitalist Revolution (Harcourt, Brace \& World, 1954); D. Sciulli, Corporations vs. the Court: Private Power, Public Interests (Lynne Rienner Publishers, 1999) 
performance becoming the sole determinant of a company's value, it became increasingly difficult to represent other aspects of a corporation. The focus on short-time volatility of corporate shares to evaluate a company's merits and prospects would quickly become the only perspective from which we would try to understand a firm. ${ }^{27}$ But this narrowing of gaze came at the price of also blinding out that the firm's environment had dramatically been transformed over the course of a few decades. To the degree that the advancement of communication and information technology revolutionized the transfer of derivatives, sometimes as a company's virtual assets, across vast strategic spaces, the attention given to stock performance eventually removed the firm from its geographical environment by elevating it into a purely ethereal realm. In consequence of its financialization, the share or other security of the corporation (its 'reference asset' for the creation of another synthetic security) became radically virtualised. What architects of synthetic credit instruments call the reference asset, which can be the original subject of a loan or security, became radically virtualised in relation to the business corporation. The corporation, in turn, was reduced to an anchoring point for independently originated financial programs, thereby positioning the corporation no longer in a real economy, but in an artificial space of financial engineering.

In the end the firm as we have come to understand it over the past 20 years, had even outgrown even the ideal model of a nexus of contracts. ${ }^{28}$ In order to remain operational, the model had to be adapted to the processes of financial engineering, which - at least partially - moved the corporation out of the centre of the labyrinth of contracts in which it, or its securities, are entangled. The financialization of the corporation and its securities entailed a radical separation of the corporation itself from the instruments that represent claims in, of, or against the corporation. The corporation had become a nodal point for an ephemeral crossing,

${ }^{27}$ W. Lazonick/M. O'Sullivan, 'Maximizing Shareholder Value: A New Ideology for Corporate Governance', in W. Lazonick and M. O'Sullivan (eds.), Corporate Governance and Sustainable Prosperity (Palgrave Macmillan, 2002)

${ }^{28}$ For a reminiscence, see A. A. Alchian/H. Demsetz, 'Production, Information Costs, and Economic Organization', (1972) 62 American Economic Review 777-795; M. C. Jensen, A Theory of the Firm. Governance, Residual Claims, and Organizational Forms (Harvard University Press, 2000). 
interlinking and overlapping of financial vectors, channelled through the glass structure of the legal person, with almost to no relation to the original 'business' of the corporation. A dream fulfilled, with money flowing in and out of the firm, the corporation had become a virtual realm for strategic investment.

The financialization of corporate governance is powerfully reflected in the fast rise in importance of financial experts in the board of directors, the importance of financial expertise in the making of business decisions and, finally, in the transformation of the educational environment for the supporting professions - including lawyers, consultancies and accountants. The flip-side of this is the dramatic erosion of labour interests representation in the contemporary business corporation. Where corporate activity had for a long time been marked by a lively public political discussion of different constituencies' interests in the firm, its financial and physical virtualization ${ }^{29}$ increasingly erased the reference points for a general assessment of what corporations were doing.

\section{B. TRANSFORMATIONS OF CAPITALISM AND THE LAW}

This context is of crucial importance for any inquiry into the prospects of Corporate Social Responsibility. One of the reasons for the dismal history of CSR must be seen in the disjuncture between the by-then-attained complexity of corporate activity on the one hand and the comparably crude regulatory attempts with regard to the corporation and its financialization, on the other ${ }^{30}$, which characterized the larger part of the twentieth century. As the contestation of the firm and the inquiry into its duties and obligations continued, decade after decade, along oversimplified and yet politically and normatively highly charged dividing

${ }^{29}$ See, e.g., W. H. Davidow/M. S. Malone, The Virtual Corporation. Structuring and Revitalizing the Corporation for the 21st Century (Harper Collins, 1992); for the foundations, see M. Castells, The Rise of the Network Society, The Information Age: Economy, Society and Culture, Vol. I. (2nd ed., 2000) (Blackwell, 1996).

${ }^{30}$ H. Mintzberg, 'The Case for Corporate Social Responsibility', (1983) 4 Journal of Business Strategy 3-15, 14 
lines $^{31}$, there were but few attempts at stepping back from the lines of attack to take a fresh perspective on what a business corporation is all about. $^{32}$ Too immersed into the evolving environment of industrial capitalism were all observers of the firm to recognize it as anything else than a vehicle of wealth-enhancing, general social progress. In the heated dispute between 'shareholder value' and 'stakeholder capitalism', in particular in light of the self-proclaimed triumph of the former as representing the 'end of history in corporate law', ${ }^{33}$, those who purported to hold on to a system of an embedded system of corporate governance ${ }^{34}$ thus long remained on the losing side of the argument. In this context, most of the arguments pointing to the political nature of the firm as a public or quasi-public actor in a world of privatization, growing corporate influence in public-private infrastructure development and the market principle-driven organization and maintenance of formerly public services

${ }^{31}$ A. B. Carroll, 'A History of Corporate Social Responsibility. Concepts and Practices', in A. Crane,A. McWilliams,D. Matten,J. Moon and D. S. Siegel (eds.), Oxford Handbook of Corporate Social Responsibility (Oxford University Press, 2008)

${ }^{32}$ But, see C. D. Stone, Where the Law Ends. The Social Control of Corporate Behavior (Harper Row, 1975), and the contributions to G. Teubner/L. Farmer/D. Murphy (eds.), Environmental Law and Ecological Responsibility: The Concept and Practice of Ecological Self-Organization (Wiley, 1994); regarding the more recent debate about the 'moral hazard' of corporate lawyers, spurred particularly, perhaps, by the revelations of unethical behavior, see, e.g., Deborah Rhode \& Paul Paton, 'Lawyers, Ethics and Enron' (2002) Stanford Journal of Law, Business and Finance 9; Paul Paton, 'Corporate Counsel as Corporate Conscience: Ethics and Integrity in the Post-Enron Era' (2006) 84 La Revue du Barreau Canadien 533; Mark A. Sargent, 'Lawyers in the Moral Maze' (2004) 49 Villanova L. Rev. 867, and Geoffrey Miller, 'From Club to Market: The Evolving Role of Business Lawyers' (2005-2006) 74 Fordham L. Rev. 1005

${ }^{33}$ H. Hansmann/R. Kraakman, 'The End of History for Corporate Law', (2001) 89 Geo. L. J. 439-468; see the more recent reassertion: H. Hansmann, 'How Close is the End of History?' (2006) 31 J. Corp. L. 745-750; for a critique see A. Rebérioux, 'The end of history in corporate governance? A critical appraisal', (2004) Amsterdam Research Centre for Corporate Governance Regulation, Inaugural Workshop 17-18 December 2004, available at: http://www.arccgor.nl/uploads/File/Reberioux\%20Amsterdam\%202.pdf ; S. Deakin, 'Squaring the Circle? Shareholder Value and Corporate Social Responsibility in the U.K.' (2002) 70 George Washington Law Review 976-987

34 See, e.g., R. Dore/W. Lazonick/M. O'Sullivan, 'Varieties of Capitalism in the Twentieth Century', (1999) 15 Oxford Review of Economic Policy (Oxford Rev. Econ. Pol'y) 102-117. 
were never seen to carry much weight, given the soberingly amorphous nature of the political economy in general. ${ }^{35}$ With the state, seen domestically, in a strange to-and-fro between retreat and re-regulation and, perceived globally, as trying to expand its regulatory reach towards actors and processes that had long been powerfully unfolding in the transnational space $^{36}$, the long-recognized anchor-point for a political theory of the firm was lost - and with it the place of corporate governance within a larger project of critical regulatory inquiry. ${ }^{37}$

\section{CRISIS - WHAT CRISIS?}

In October 2008, much of this debate appears in a different light, with exorbitant values being 'wiped out' - as the stock market talk goes - at breathtaking speed. ${ }^{38}$ At the end of September 2008 the drama of a Federal Bailout program in the United States progressed on a breath-taking course, and its outcome is anything but clear. ${ }^{39}$ With each passing day, the hopes that the USD $700 \mathrm{Bn}$ injection would have a real effect, become dimmer. At the same time, the global dimensions of the credit crisis become clearer and attempts to address the crisis are being undertaken on a global level.

${ }^{35}$ For a sobering account, see H. W. Arthurs, 'The Administrative State Goes to Market (and Cries 'Wee, Wee, Wee' All the Way Home)', (2005) 55 U. Toronto L. J. 797-831

${ }^{36} \mathrm{C}$. Villiers, 'Corporate law, corporate power and corporate social responsibility', in N. Boeger,R. Murray and C. Villiers (eds.), Perspectives on Corporate Social Responsibility (Edward Elgar, 2008); and D. Patterson/A. Afilalo, The New Global Trading Order. The Evolving State and the Future of Trade (Cambridge University Press, 2008), chapters 2, 3.

${ }^{37}$ P. Zumbansen, 'The Parallel Worlds of Corporate Governance and Labor Law', (2006) 13 Indiana Journal of Global Studies 261-312

${ }^{38}$ On 30 September 2008, Bloomberg News services reported the loss of over 1 trillion US dollars market value, see http://www.bloomberg.com/apps/news?pid=20601087\&sid=apYf0gSb6.HQ\&refer=hom $\underline{\mathrm{e}}$

${ }^{39}$ M. Landler \& E. L. Andrews, 'For Treasury Dept., Now Comes Hard Part of Bailout', New York Times, 3 October 2008, available here (last accessed 4 October 2008) 
Yet, it is all too obvious that this extreme value destruction speaks to the similarly overwhelming, 'irrationally exuberant' ${ }^{40}$ creation of value that marked the last two decades, albeit with some momentary interruptions. ${ }^{41}$ In light of the securitization mania, which George Soros scandalized in his most recent book ${ }^{42}$, the long emerging impression that we were witnessing an irrevocable, fundamental shift from industrial to financial capitalism appears questionable now. A host of rescue teams is waiting on the sideline, but where are these suggestions directing us? Polanyi's return? ${ }^{43}$ What would have appeared, just a few years ago, as an at best inopportune attempt at applying a purportedly outdated political economy approach to a host of economic processes that seemed to defy political regulation in the name of a boastingly triumphant market fundamentalism, might today be able to critically inform a disparaged discourse over the future of financial market regulation. The latter is intricately intertwined with corporate governance, and thus intimately tied to any discussion of CSR. It is against this background, that today's search into the soul of the market and the company is unfolding.

\section{RE-EMBEDDING CAPITALISM?}

Hence, the suggestion to take three points of departure for a new look at the idea and concept of corporate social responsibility. By proposing three paradigms that can structure and explain the evolution of our thinking of CSR, I hope to illustrate the above-alluded to connections between the triadic regulation of finance, corporate governance and labor. CSR cannot be assessed without taking this constellation as one of several cornerstones

${ }^{40}$ R. J. Shiller, Irrational Exuberance, 2nd ed. (Currency Doubleday, 2005)

${ }^{41}$ See only Joseph Stiglitz, The Roarding Nineties. A New History of the World's Most Prosperous Decade (2003).

42 G. Soros, The New Financial Paradigm. The Credit Crisis of 2008 and What It Means (Public Affairs, 2008), at xvii.

43 See, e.g., M. J. Piore, 'Second Thoughts: On Economics, Sociology, Neoliberalism, Polanyi's Double Movement and Intellectual Vacuums', (2008) Society for the Advancement of Socio-Economics, Presidential Address July 22 for an intriguing inquiry into the possibility of framing regulatory challenges today through the lens of Polanyi's 'double movement' 
for a theory of the firm. With this regulatory triad evolving in different political economies through history, we will see how the identification of different regulatory challenges is inevitably always a child of its time. The deafening noise of political contestation is likely to repeatedly point our attention to 'usual' suspects of interest carriers in and around the business corporation, managers, investors, unions, employees, creditors, the infamous 'society at large'. Despite the embeddedness of the business corporation in historically evolved socio-economic contexts, it simultaneously lives in other worlds as well. The political economy of the firm is not all there is to its persisting regulatory conundrum as long as our analytical lens ("political economy") can only perceive the corporation as either a 'legal personality' or as a 'real' actor to which it then assesses attributes such as 'private', 'quasi-public', 'political', or 'hybrid'. Both perspectives - the legal and a crude, sociological one - that merge in the political economy approach, must be enlarged: the legal perspective must incorporate its greatest challenge, namely all that which is not law. Within the legal system, this suggests a burning tension between legal/illegal and non-legal. ${ }^{44}$ From that perspective, the concept of the corporation as a legal person must be deconstructed in order to question the relation between the legal and non-legal norms that govern corporate behavior. In light of the fast growing body of self-regulatory norms, such an inquiry seems more than warranted. Second, with regard to the sociological struggle over naming the corporate beast, it seems no longer plausible to apply terms (private, public, political) and derivations thereof (quasipublic, hybrid) to describe entities, that seem to evolve in defiance of traditional concepts used to describe the relations between the state and the market. After a Realist/legal-sociological destruction of the allegedly apolitical, non-legal nature of the "market" ${ }^{45}$ on the one hand and the evolving paradigm of the knowledge society in sociological thinking on

\footnotetext{
${ }^{44}$ G. Teubner, 'Self-subversive Justice: Contingency or Transcendency Formula of Law?' (2008) Modern Law Review forthcoming

${ }^{45}$ See only R. L. Hale, 'Coercion and Distribution in a Supposedly Non-Coercive State', (1923) 38 Political Science Quarterly 470-494; R. Pound, 'The New Feudalism', (1932) 16 American Bar Association Journal 553-558 [bereits abgedruckt als: The New Feudal System, Commercial Law Journal 397-403 35 (1930), 397-403]; R. Pound, 'Public Law and Private Law', (1939) 24 Cornell Law Quarterly 469-482
} 
the other ${ }^{46}$, we need to turn our attention to that which lies beyond the traditional political economy approach. At the end of our present inquiry, we shall see how the last paradigm, which purports to reformulate corporate social responsibility as a general theory of corporate function in a knowledge society is at this time the least concretely defined one. It is a concept in evolution, and still crucially experimental. And yet, a cursory study of the preceding two paradigms, the organizational-industrial and the financial one, will illuminate a trajectory, which records the first two paradigms as epochs in an evolutionary, open-ended development.

\section{INDUSTRIAL ORGANIZATION AND CORPORATE Governance (PARAdigM 1)}

The study of the first paradigm is fairly straightforward. It includes a revisiting of the well-known dialectics between mainstream corporate governance and CSR promoters. Let us call this paradigm the "Organizational-Industrial or, the Economic Paradigm". From this conceptual viewpoint, the dispute is one about conflicting ordering values for political economy models. It is here, where a comparative perspective is of crucial importance ${ }^{47}$ in light of the fact that CSR discourses form part of highly path-dependent, historically evolving and socio-culturally defined negotiations over the role of business in society. ${ }^{48}$

Given this complex landscape, no wonder that any attempt to draw up a comprehensive map is faced with considerable obstacles. Like a red thread running through the $20^{\text {th }}$ century's history of CSR we see the eternal negotiation and renegotiation of the rights and duties that structure the

${ }^{46}$ N. Stehr, Knowledge and economic conduct: the social foundations of the modern economy (University of Toronto, 2002), in particular ch. 3

47 Cynthia Williams and Ruth Aguilera, Corporate Social Responsibility in a Comparative Perspective, in: A.Crane/A.McWilliams/D.Matten/J.Moon/D.Siegel eds., Oxford Handbook of Corporate Social Responsibility (Oxford, 2007), 452-472

${ }^{48}$ Very instructive in this regard: David R. Levy and Rami Kaplan, Corporate Social Responsibility and Theories of Global Governance. Strategic Contestation in Global Issue Arenas, in: Crane et al. (eds), supra note 2, 432-451, at 442-445. 
relation between a company and its employees. ${ }^{49}$ This history reaches back, in fact, deep into the $19^{\text {th }}$ century: already in the 1800 s the negotiation of workers' rights suggested the conceptualisation of holistic concepts of workers' workplace and employment relations, expanding from the contract of employment to the establishment of supporting institutions ${ }^{50}$, albeit with considerable variations. ${ }^{51}$

\section{A THE CORPORATION AND ITS STAKEHOLDERS}

These fragments can be seen as early representations of later institutionalised prominent elements of the employee-company relation, for example in Germany ${ }^{52}$, but also in France ${ }^{53}$ and Italy. With significant differences between various national economies, the institutionalisation of worker rights took distinct forms, allowing economists and social scientists to study these differences through the lens of "varieties of

${ }^{49}$ See, e.g., R. F. Bensel, The Political Economy of American Industrialization, 18771900 (Cambridge University Press, 2000); S. M. Jacoby, The Embedded Corporation. Corporate Governance and Employment Relations in Japan and the United States (Princeton University Press, 2004).

${ }^{50}$ A. B. Carroll, 'A History of Corporate Social Responsibility. Concepts and Practices', in A. Crane,A. McWilliams,D. Matten,J. Moon and D. S. Siegel (eds.), Oxford Handbook of Corporate Social Responsibility (Oxford University Press, 2008), 19-46, at 21, mentioning hospital clinics, bath houses, lunch rooms etc.; for a larger perspective on this, see only A. Supiot, Au-delà de l'emploi. Transformation du travail et devenir du droit du travial en Europe. Rapport pour la Commission européenne. (Flammarion, 1999)

${ }^{51}$ L. E. Mitchell, The Speculation Economy. How Finance Triumphed over Industry (Berrett-Koehler Publishers, 2007); D. T. Rodgers, Atlantic Crossings. Social Politics in a Progressive Age (Belknap Harvard, 1998)

${ }^{52}$ G. Jackson, 'The Origins of Nonliberal Corporate Governance in Germany and Japan', in W. Streeck and K. Yamamura (eds.), The Origins of Nonliberal Capitalism (Cornell University Press, 2001); K. Thelen, 'Varieties of Labor Politics in the Developed Democracies', in P. A. Hall and D. Soskice (eds.), Varieties of Capitalism (Oxford University Press, 2001)

${ }^{53}$ M. J. Roe, Political Determinants of Corporate Governance (Oxford University Press, 2003) [...]; J.-P. Robé, 'L'entreprise oubliée par le droit', in: 1. Juni available at: http://www.ecole.org; J. Fanto, 'The Role of Corporate Law in French Corporate Governance', (1998) 31 Cornell Int'l L.J. 31-91 
capitalism". 54 The comparative historical narrative of these varieties became, over the course of the $20^{\text {th }}$ century, a crucial element in an increasingly global discourse over the most competitive national economy. As markets continued to follow the course of disembeddedness that had so powerfully been described by Karl Polanyi in the $1940 \mathrm{~s}^{55}$, the regulation of business enterprises fast became a strategic token in the global race for resources. With corporations being increasingly able to take their domestic regulators hostage by threatening to take their business elsewhere in search of a more supporting regulatory environment, governments soon had to recognize that their approach to corporate governance regulation was inseparable from its policies in the areas of taxation, employment law, social insurance law, industrial relations and, eventually, environmental law. From this perspective, company law regulation came to be recognized as an integral part of a government's politics of market regulation. But, to the degree to which this realization rendered regulators more sensitive and humble - with regard to the fragile constitution of a complex regulatory field, governments also became painfully aware of the limits of their interventions.

In this context, CSR was deeply entangled in the right-left negotiations of which directions political regulation of this comprehensive field of corporate governance was to take. ${ }^{56}$ At the core of this negotiation was the tension between the firm as a real, economic, social entity on the one hand and a legal person on the other. Reaching back deep into the social philosophies of the $19^{\text {th }}$ century, the negotiation of the nature of the corporation presented an opportunity to revisit and contest the evolving nature of a country's political economy. ${ }^{57}$ The high point of this inspection was the early $20^{\text {th }}$ century dispute over the duties of management. It was

${ }^{54}$ See P. A. Hall/D. Soskice (eds.), Varieties of Capitalism. The Institutional Foundations of Comparative Advantage (Oxford University Press, 2001)

${ }^{55}$ K. Polanyi, The Great Transformation. The Political and Economic Origins of our Time (Beacon Press, 1944)

${ }^{56}$ G. Jackson, 'Comparative Corporate Governance: Sociological Perspectives', in J. Parkinson,G. Kelly and A. Gamble (eds.), The Political Economy of the Company (Hart Publishing, 2000)

${ }^{57}$ F. Klein, Die neueren Entwicklungen in Verfassung und Recht der Aktiengesellschaft (Manzsche k.u.k. Hof-Verlags- und Universitäts-Buchhandlung, 1904); W. Rathenau, Vom Aktienwesen (S. Fischer, 1918) 
clear to all that what was at stake was nothing less than a political theory of the business corporation. Yet, with the dramatic expansion of the market and the crucial role of the firm within it, the political nature of the business corporation became re-channelled into a assessment over how much else the corporation should be doing with regard to protecting a wider range of interests: as a result, a new dispute opened up that would, as we know, tragically shift the focus away from the firm as such towards a firm with considerable philanthropic duties. Early litigation tells a fascinating story of these changing shifts in perspective. ${ }^{58}$

\section{B. THE CORPORATION IN A WELFARIST 'MIXED ECONOMY'}

Against the background of the expanding regulatory and welfare state in Western states, CSR experienced an important revitalisation and further consolidation in the second half of the $20^{\text {th }}$ century. As the state continued to reach deeper and deeper into every corner of society, corporations consolidated their role as vitally important actors in the fast-progressing 'mixed economy' that had already taken its beginnings - as regards certain industries - in the mid- $19^{\text {th }}$ century ${ }^{59}$ and that would become characteristic of political economy ${ }^{60}$, where corporations played a pivotal part in the state's pursuit of full employment, universal education and health care.

58 See Lochner v. New York, 195 U.S. 45 (1905) here; Dodge v. Ford Motor Co, 204 Mich. 459, 170 N.W. 668 (1919), here; but see Lynn Stout, 'Why We Should Stop Teaching Dodge v. Ford', UCLA School of Law, Law \& Economics Research Paper, available at: http://ssrn.com/abstract=1013744, for the argument that, despite this Court's "gone astray" ruling, U.S. corporate law does in fact not mandate a management's legal duty to maximize shareholder value.

${ }^{59}$ With regard to France, see P. Weil, Le Droit Administratif (9ême éd. 1980) (Presses Universitaires de France, 1964), chap II. (reflecting on the way that the mixed economy affected the choice of regulatory instruments of administrative agents); see also F. Ewald, L'Etat providence 1986), at 111: "Le rêve d'une société où chacun ne dépendrait plus que de lui-même, de sa volonté et de sa liberté, l'utopie d'une société de prévoyance avaient vécu. Le patron devait maintenant, dans la conduite de ses affaires, viser l' " amelioration morale et matérielle » de ses ouvriers.” With view to the concurring, staged triumph of laissez-faire in Britain and the U.S., see R. H. Tawney, The Acquisitive Society (Harcourt, Brace and the World, 1920) ; K. Polanyi, The Great Transformation. The Political and Economic Origins of our Time (Beacon Press, 1944), 135, 139 (Britain)

60 H.-D. Assmann, Wirtschaftsrecht in der Mixed Economy (Athenäum, 1980); G. Frankenberg, 'Shifting Boundaries: The Private, the Public, and the Welfare State', in M. 
At the same time, the concept of a mixed economy remained anything but uncontested. ${ }^{61}$ It was clear that its mobilization constituted an invitation, if not a provocation to either critically assess the relation between state and market or to deconstruct the allegedly neutral role of the state and the 'private' nature of the market. One illustration of this unresolved, dormant dispute was the lingering doctrinal and conceptual ambiguity surrounding legal regulatory fields such as 'economic' or 'social' law. ${ }^{62}$ The contested categorization of different fields to belong to either 'private' or 'public' law could either be seen as a significant (or, bizarre) manifestation of civil law private lawyers' obsession with formal-doctrinal distinctions, or as a

B. Katz and C. Sachße (eds.), The Mixed Economy of Social Welfare (Nomos, 1996); G. Frankenberg, 'Udo Di Fabio's Die Kultur der Freiheit and Richard Sennett's Die Kultur des neuen Kapitalismus', (2006) 7 German L. J. 721-728

${ }^{61}$ See A. Shonfield, Modern Capitalism. The Changing Balance of Public and Private Power (Oxford University Press, 1965), 82-84 (regarding France); H.-J. Chang, 'Kicking Away the Ladder. An Unofficial History of Capitalism, Especially in Britain and the United States', (2002) 45 Challenge 63-97, 77 (Britain); see also N. Luhmann, 'Capitalisme et Utopie', (1997) 41 Arch. phil. droit 483-492, at 488: "L'utopie qui permet une coexistence du système politique et du système économique, sous reserve de la différenciation fonctionelle, porte le nom d' " économie sociale de marché » Du point de vue politique cette formule indique que l'on veut et que l'on peut réaliser en un seul système les objectifs du système capitaliste et du système socialiste." See the acid refutation by F. A. Hayek, The Mirage of Social Justice [Law, Legislation and Liberty. A new statement of the liberal principles of justice and political economy, vol. 2] (The University of Chicago Press, 1976), 62-106 ('Social' or Distributive Justice), at 101: "It seems that among the younger generation the welfare institutions into which they have been born have engendered a feeling that they have a claim in justice on 'society' for the provision of particular things which it is the duty of that society to provide. However strong this feeling may be, its existence does not prove that the claim has anything to do with justice, or that such claims can be satisfied in a free society."

${ }^{62}$ R. Wiethölter, 'Die Position des Wirtschaftsrechts im sozialen Rechtsstaat', in H. Coing,H. Kronstein and E.-J. Mestmäcker (eds.), Wirtschaftsordnung und Rechtsordnung, Festschrift für Franz Böhm zum 70. Geburtstag (Siebeck Mohr, 1965); R. Wiethölter, Rechtswissenschaft (Fischer, 1968), 168; F. Ewald, 'A Concept of Social Law', in G. Teubner (eds.), Dilemmas of Law in the Welfare State (Walter de Gruyter, 1985); E.-J. Mestmäcker, 'Das Verhältnis der Wirtschaftswissenschaft zur Rechtswissenschaft im Aktienrecht', in L. Raiser,H. Sauermann and E. Schneider (eds.), Das Verhältnis der Wirtschaftswissenschaft zur Rechtswissenschaft. Soziologie und Statistik (Duncker \& Humblot, 1964) 
far-reaching critique of the unquestioned political normative foundations of legal regulation. $^{63}$

Despite this, the next period was marked by a number of noteworthy highpoints in the polemical debate over the scope of a company's obligations and duties "to society" 64 Let us briefly turn our attention to the famous, infamous uttering by Milton Friedman, which since then has haunted CSR proponents: In response to the question, "What does it mean to say that the corporate executive has a 'social responsibility' in his capacity as businessman?”, Friedman answered ${ }^{65}$ :

"If this statement is not pure rhetoric, it must mean that he is to act in some way that is not in the interest of his employers. For example, that he is to refrain from increasing the price of the product in order to contribute to the social objective of preventing inflation, even though a price increase would be in the best interests of the corporation. Or that he is to make expenditures on reducing pollution beyond the amount that is in the best interests of the corporation or that is required by law in order to contribute to the social objective of improving the environment. Or that, at the expense of corporate profits, he is to hire 'hardcore' unemployed instead of betterqualified available workmen to contribute to the social objective of reducing poverty." [...]

"In each of these cases, the corporate executive would be spending someone else's money for a general social interest. Insofar as his actions in accord with his 'social responsibility' reduce returns to stockholders, he is

63 R. Wiethölter, 'Artikel Wirtschaftsrecht', in A. Görlitz (eds.), Handlexikon zur Rechtswissenschaft (Wissenschaftliche Buchgesellschaft, 1972)

${ }^{64}$ See only Milton Friedman, 'The Social Responsibility of a Corporation is to Increase its Profits', New York Times Magazine, 13 September 1970, available here (last accessed 4 October 2008).

65 The following quotes are excerpted from Joel Makover, 'Milton Friedman and the Social Responsibility of Business', World Changing.com, 19 November 2006, available at: http://www.worldchanging.com/archives/005373.html (last accessed 4 October 2008). 
spending their money. Insofar as his actions raise the price to customers, he is spending the customers' money. Insofar as his actions lower the wages of some employees, he is spending their money." [...]

Friedman concluded:

"The difficulty of exercising 'social responsibility' illustrates, of course, the great virtue of private competitive enterprise -- it forces people to be responsible for their own actions and makes it difficult for them to 'exploit' other people for either selfish or unselfish purposes. They can do good -- but only at their own expense."

The central point for our purposes is Friedman's distinction between the responsibilities of an individual and a corporation. He asks: "What does it mean to say that "business" has responsibilities? Only people can have responsibilities. A corporation is an artificial person and in this sense may have artificial responsibilities, but "business" as a whole cannot be said to have responsibilities, even in this vague sense. The first step toward clarity in examining the doctrine of the social responsibility of business is to ask precisely what it implies for whom.”

The powerless critique of business made by proponents of CSR can be seen in their inability to effectively counter this argument. And, against the background of the late $19^{\text {th }}$, early $20^{\text {th }}$ century political economy with the creation of the corporation in law as legal person, this would have been relatively obvious: Friedman's refutation of any attempt to attribute general social obligations to the business firm is grounded in the idea that a corporation is a physical entity, created and structured through a series of private agreements among individual business people. Attributing a general social responsibility to a corporate manager would, in Friedman's view, constitute both an unwarranted expansion of his duties and a nonpermissable violation of management's duties to its employers - that is the firm's shareholders. Friedman comes dangerously close to a recognition of the firm's legally constructed artificial reality when comparing a manager to a civil servant. Friedman here suggests that were a manager to be likened to a civil servant, which would inevitably include an assignment of additional and different duties, then there ought to be, for starters, a 
different appointment or election process. It is here where Friedman not only recognizes the concept of the legal person, but he is effectively exploiting it, implying that it is in the prerogative of the legislator to change these ground rules. But, as long as they remain in place, it is not in the purview of judges (or scholars) to arbitrarily expand the existing range of obligations.

It is too obvious to see how this argument goes in circles, but it does and has been doing so very effectively. At the heart of this is that management's duty exhausted itself in meeting shareholders' demands. This merely includes another conundrum, namely what shareholder interests are. Such an assessment can simply not be made in the abstract. This is the most important lesson from the recent revisiting of Berle and Means' 1932 book and the much-needed project to re-embed the book in the contemporary political economy in order to undermine the mainstream narrative that has been seeking to use their book as a vanguard publication for a shareholder value maximization program. ${ }^{66}$ The first paradigm for CSR, which embeds its concept and idea in a larger political economy has, in the end, to run dry, because it cannot effectively penetrate the black box of corporate law regulation, which remains sealed with a thick layer of inconclusive statements over duties and obligations. The crux has been the following: on the one hand, the corporation is perceived as a contractual arrangement through which it channels its own and so-called 'residual' interests. $^{67}$ On the other hand, the corporation is rightly perceived as a legal person, that is, the corporation is the result of an artificial construction, which shields the owners from the corporation's creditors. ${ }^{68}$ As such, however, it is the subject of legal construction, regulation and interpretation. Put bluntly, the corporation as a legal framework exists but through authority of the law, and it is through law that the conflict between distance and care, between public intervention and private autonomy is constantly being renegotiated. The firm becomes the

${ }^{66}$ W. W. Bratton/M. L. Wachter, Shareholder Primacy's Corporatist Origins: Adolf Berle and The Modern Corporation, available at http://ssrn.com/abstract=1021273 2007).

${ }^{67}$ E. Fama/M. C. Jensen, 'Agency Problems and Residual Claims', (1983) 26 Journal of Law and Economics 327-349

${ }^{68}$ R. Kraakman/P. L. Davies/H. Hansmann/G. Hertig/K. J. Hopt/H. Kanda/E. B. Rock, The Anatomy of Corporate Law. A Comparative and Functional Approach (Oxford University Press, 2004) 
laboratory, in which Polanyi's double movement of market liberalization and market control is seemingly inescabably intertwined. Certainly, this does not in any way solve the problem how to negotiate the principle of private autonomy and legal construction within the company, unless one chooses to collapse the distinction between the allegedly private sphere of contractual arrangements here and political intervention there. This move is well known and has been made again and again throughout the $20^{\text {th }}$ century. ${ }^{69}$ But, because it reengages the concept of the corporation in a debate which is at once legal, political and moral, this debate is necessarily open-ended. It would already be an advance to view CSR as reflective of this open-ended dispute, not as its solution.

\section{BEYOND RIGHT AND LEFT?}

As we will see in the following section, the political economy paradigm, as unfolded up to here, has been seriously undermined and relativized by the increasing disempowerment of the invested interest parties in the corporation. The degree to which the received nexus-of-contracts model fails to explain the financial flows, subdivisions and reshapings of business corporations today reflects on the differentiation of the corporate form. As the modern business corporation becomes, on the one hand, the intersection for strategic investments, and, on the other, a dramatically decentralized, 'networked' firm ${ }^{70}$, its traditional organizational structure begins to dissolve. We are only beginning to understand the consequences this has for our analytical apparatus. As regards the former, the dramatic rise of financial instruments, special investment vehicles and funds

${ }^{69}$ D. Kennedy, 'Legal Formality', (1973) 2 J. Leg. Stud. 351-398; D. Kennedy, 'Form and Substance in Private Law Adjudication', (1976) 89 Harv. L. Rev. 1685-1778; W. W. Bratton, 'The 'Nexus of Contracts' Corporation: A Critical Appraisal', (1989) 74 Cornell L. Rev. 407-465; W. W. Bratton, 'Welfare, Dialectic, and Mediation in Corporate Law', (2005) 2 Berkeley Bus. L.J. 59-76

${ }^{70}$ W. W. Powell, 'Neither Market nor Hierarchy: Network Forms of Organization', (1990) 12 Research in Organizational Behavior 295-336; L. Smith-Doerr/W. W. Powell, 'Networks and Economic Life', in N. J. Smelser and R. Swedberg (eds.), Handbook of Economic Sociology, 2nd ed. (Princeton University Press/Russell Sage, 2005); C. K. Prahalad/M. S. Krishnan, The New Age of Innovation. Driving Co-Created Value Through Global Networks (McGraw Hill, 2008) 
suggests a far-reaching erosion of the traditional, publicly held stock corporation. The eroding effect this has on the interest pluralism concept of the corporation, even with its iterations of a mixed, hybrid, quasipolitical actor, is exacerbated by the networked firm, which continues to pose formidable challenges for traditional political economy concepts of the corporation and its stakeholders. ${ }^{71}$

We are increasingly facing the dilemma of having to describe a fastevolving, complex structure without having the appropriate vocabulary available. In light of the political economy perspective described above, the combination of a sophisticated, critical legal perspective and a yearning sociological description seems to be all we have at our disposition. The promise of trying to rescue the political economy perspective into the next evolutionary, more radically financial phase of corporate organization, is that we might be able to translate our inquiry over the meaning of public and private in corporate law into an adequately critically agenda for the corporation in an era of financial capitalism. The danger of studying the corporation through the lens of political economy is that we are likely to apply the same distinctions as we used to, without

71 See, for example, L. Boltanski/È. Chiapello, Le nouvel esprit du capitalisme (Gallimard, 1999), 291 [engl. ed. 2002, 217], K. V. W. Stone, 'The New Psychological Contract: Implications of the Changing Workplace for Labor and Employment Law', (2001) 48 UCLA Law Review 519-659, H. W. Arthurs/C. Mummé, 'From Governance To Political Economy: Workers As Citizens, Stakeholders and Productive Social Actors. Paper for the First International CLPE Conference: The Corporate Governance Matrix: Unfolding the New Agenda, Osgoode Hall Law School, Toronto, 20-21 October 2005', (2005) CLPE Research Paper Series (www.comparativeresearch.net) , and R. Sennett, The Culture of the New Capitalism (Yale University Press, 2006) with regard to the challenges for labour and employment rights; but see C. Scott, 'Reflexive governance, meta-regulation and corporate social responsibility: the 'Heineken effect", in N. Boeger,R. Murray and C. Villiers (eds.), Perspectives on Corporate Social Responsibility (Edward Elgar, 2008), whose concept of reflexive governance requires us to treat the network as a 'learning' entity for which 'law' can only be seen as one part of an evolving normative framework that is created by different state and non-state actors and out of which the identification of CSR obligations takes place; compare with a varieties-of-capitalism approach to a hybrid governance model of the innovative and the learning firm: W. Lazonick, 'Varieties of Capitalism and Innovative Enterprise', (2007) 24 Comparative Social Research 21-69 and P. Zumbansen, 'Varieties of capitalism and the learning firm: corporate governance and labour in the context of contemporary developments in European and German company law', in N. Boeger,R. Murray and C. Villiers (eds.), Perspectives on Corporate Social Responsibility (Edward Elgar, 2008) 
however, being able to develop them against the former political, regulatory and socio-economic framework. While early critics of legal formality with regard to the corporation believed in the validity of repoliticization $^{72}$, this is anything but certain today. For one, the institutional framework of political market regulation has been undergoing dramatic changes, effectively eroding the demarcation lines between the market and the political spheres. ${ }^{73}$ While we, in critical tradition, might want to continue to discredit the validity of these boundaries in the first place, there is another element which seriously challenges the critical project: the transnationalization of legal regulation leads to a complex co-existence of legal and non-legal forms of governance and self-regulation. With the deterritorialization of societal activities on the one hand and the proliferation of norm-entrepreneurs designing norms and regulatory regimes for these cross-jurisdictional spaces of societal activity on the other, the space of political action is being redefined. ${ }^{74}$ With law having become unearthed, the survival chances of a nation-based concept of legal regulation have become uncertain. ${ }^{75}$ With this in mind, it is questionable whether a political economy perspective can help us understand today's regulatory challenges with regard to the complex forms of the corporation.

As we will see when discussing the next paradigm, the relegation of the political economy perspective is not a viable option when trying to understand the particular position of CSR in a web of transnationalized legal, economic, social and political rationalities. While not offering a relief from the ambiguous role of CSR in the larger context of capitalist organization, the political economy paradigm nevertheless helps to

\footnotetext{
${ }^{72}$ R. L. Hale, 'Coercion and Distribution in a Supposedly Non-Coercive State', (1923) 38 Political Science Quarterly 470-494; A. A. Berle, The 20th Century Capitalist Revolution (Harcourt, Brace \& World, 1954)

${ }^{73}$ A. C. Aman Jr., 'Administrative Law for a New Century', in M. Taggart (eds.), The Province of Administrative Law (Hart Publishing, 1997); O. Lobel, 'The Renew Deal: The Fall of Regulation and the Rise of Governance in Contemporary Legal Thought', (2004) 89 Minn. L. Rev. 342-469; R. B. Stewart, 'Regulation, Innovation, and Administrative Law: A Conceptual Framework', (1981) 69 Cal. L. Rev. 1256-1377

${ }^{74}$ G.-P. Calliess/P. Zumbansen, Rough Consensus and Running Code: A Theory of Transnational Private Law forthcoming)

${ }^{75}$ N. Luhmann, Law as a Social System (K.Ziegert transl., F.Kastner, D.Schiff, R.Nobles, R.Ziegert eds.) (Oxford University Press, 2004), at 497.
} 
become adequately sensitive when assessing the complex landscape of corporate governance regulation today. But, as we will see, the political economy perspective's endorsement of a categorical distinction of economy and society prevents it from adequately registering the economy as one function system of society. ${ }^{76}$

\section{What Comes After Financial Capitalism? (PARAdigm 2)}

Let us now turn to a brief examination of the second, already alluded to financial paradigm for CSR. It provides for a different perspective by focusing on CSR as an integral element of any business decision taken by corporate management. Given the emphasis on the financial strategies that business corporations have been pursuing on global markets over the past, "The Financial Paradigm" offers important insights into the way in which the corporation has been transformed from a fairly straightforward investment, production and dissemination vehicle into a complex amalgamation of financial strategies, consuming every corporate asset and interest.

One element of this transformation is that financial decisions in the past have been driven almost exclusively with a short-term orientation in mind, as regards the maximization of shareholder value in response to highly volatile investor constituencies who, at any time, could 'take their money elsewhere'. In this light, the Financial Sustainability Paradigm, however, already points to precisely that, which the strategies pursued by corporate management over the last two decades - in most cases - were not. Instead, our second paradigm shall help us better understand how strategies of corporate governance and corporate finance are intricately interlinked and intertwined. The meaning of the second paradigm is, hence, not to promote a return to a pre-financial capitalism model of corporate organization, but, instead, to embrace the potential of a highly diversified knowledge economy, which bears substantial potential to better synergize governance and finance strategies in a sustainable way.

\footnotetext{
${ }^{76}$ N. Luhmann, Die Wirtschaft der Gesellschaft (Suhrkamp, 1988), ch. I
} 
The other element of the financial corporation as the key player in the transition from industrial to financial capitalism is the degree to which the claims held by various stakeholders of the firm against the corporation become themselves commodified. This is most discernible with regard to the dramatic expansion of financial instruments consuming all of a corporation's inside and outside relations.

The degree to which the narrative of a transition from industrial to financial capitalism is replete with paradoxes, similar to those we identified under the first political economy paradigm, becomes obvious when we turn our attention to the evidence given in its support. Readers of the recent 'Special Report on Globalisation' in The Economist' ${ }^{77}$ might have been struck by the display of complexity that appears to mark the contemporary wave of economic globalisation. From the various accounts covered in the Report, it seems clear that the continuing, undeterred rise of emerging market companies to economic success is likely only the tip of an iceberg of an indeed extremely multi-faceted story of marketisation and global expansion.

With consultancy firms putting in hundreds of extra hours and experts to stay informed on the rapid developments in the BRIC economy ${ }^{78}$, worldwide attention is turning to the analysis of market strategy, multinational (inter-cultural) management theory and the role of government in the economy. This interest in the global market is fuelled further by the dramatic developments in the global finance sector in 2008. ${ }^{79}$ These developments are - as we speak - continuing to grow into most dramatic proportions, and the repercussions are anything but clear. Surely, they are not promising. While the world markets are being reshaped by emerging economies' multinational companies that are powerfully contesting the stronghold of Western world companies, the biggest erosion of the financial markets since the Great Depression ${ }^{80}$,

77 A special report on Globalisation, The Economist, 20 September 2008, available at www.economist.com

${ }^{78}$ As coined by Goldman Sachs, BRIC includes Brazil, Russia, India and China.

${ }^{79}$ R. J. Shiller, The Subprime Solution. How Today's Global Financial Crisis Happened, and What to do About it (Princeton University Press, 2008)

${ }^{80}$ G. Soros, The New Financial Paradigm. The Credit Crisis of 2008 and What It Means (Public Affairs, 2008) 
perhaps ever, drives a deep wedge into the architecture of financial capitalism that has been growing out of the structures of the mid- $20^{\text {th }}$ century industrial and post-industrial market systems over the past one or two decades. The present attempts, worldwide, to effectively address the current crisis, suggest a much greater need to really understand the origins of this crisis. Coupled with the now fast emerging 'explanations of how we got here' are the usual "I told you so's", but all of these assertions continue to leave a somewhat bitter feeling that this surely cannot be all that is to it. And that is not only prompted by the sheer dramatic dimensions of the present financial fall-out and the corresponding political responses. $^{81}$ At the heart of the financialization paradigm we find the unresolved issue of how the financial concept of the firm relates to the organizational one. The problem here is the apparent amnesia of the promoters of a financialization of corporate governance with regard to the unresolved problems of the organizational concept of corporate governance, which stood at the centre of the political economy paradigm. Mistaking the past history for a closed chapter, the recent defences of a financial theory of the corporation failed to acknowledge how a different angle from which to describe the firm on its own does not provide a response to the remaining unanswered questions.

Today, much suggests that we are standing at the brink of moving beyond the financialization paradigm. As the uneasiness grows that, deep down, the dark sides of the concept of financial capitalism have been neglected in favor of exploiting the globalization, mobility and expansion theory of corporate governance $^{82}$, the question of what comes next appears nothing but daunting.

What is the place of CSR in this discourse of transition? Seemingly, CSR has little to say, being still so embedded in the contrasting paradigm of right vs left corporate politics. Yet, this should not blind us to recognize that CSR is an integral part of the current rethinking of what corporations

${ }^{81}$ See, for a critique, both Steven Schwartz, Systemic Risk, SSRN Working Paper 2008, available at http://ssrn.com/abstract=1008326, and Lucian Bebchuk, A Plan for Addressing the Financial Crisis, SSRN Working Paper, available at: http://ssrn.com/abstract $=1273241$

${ }^{82}$ For an insightful critique, see J. A. Frieden, Global Capitalism. Its Fall and Rise in the Twentieth Century (W.W. Norton \& Company, 2006), 385 ff. 
owe to society. The financialization of corporate governance is in many ways more fact than program today and this, in turn, has clear implications for CSR. CSR must embrace the expanded reach of management decisionmaking challenges and contribute to a concretisation of these duties beyond the former proclamation that the corporation has a responsibility towards society at large. At this stage of the development, the challenge is to reformulate CSR to encompass the most advanced forms of corporate finance through which the firm becomes part of a global web of financially interlinked financial instruments. From this perspective, CSR moves beyond the philanthropic confinements of its previous iterations, while not betraying its political economy origins. Rather, by taking these seriously, a timely CSR agenda must today build on the changed environment of organizational and financial architectures when formulating policies. It is here, where CSR meets SRI and many other pertinent forms of bringing 'social' considerations to bear upon corporate decision-making. Only to the degree that CSR is able to think outside of the corporate box and transform itself into a functionally driven perspective from which to perceive emerging forms of corporate activity, investment, risk diversification and securitization, will CSR have anything to say in this problematic time.

\section{WHAT MANAGERS (WE) DO DEPENDS ON WHAT THEY (WE) KNOW (PARADIGM 3)}

\section{A. The Place of KnOWLedge in Management}

Our story could end here. But, there is the promise of another perspective, which brings together the previous ones while allowing us to see how these two can be further help us to see CSR in fact as a still larger conceptual challenge. The third paradigm is “The Knowledge Paradigm”. It aims to capture the particular challenges that management faces when confronted with decision-making challenges in a global market, which is characterized by a great degree of uncertainty and risk. This paradigm opens up a new perspective on the way that management engages on a day-to-day basis in the negotiation of short-term and long-term perspectives in a context, that is both highly artificially constructed with view to the financial instruments, which management operates with, but it 
is also deeply embedded in an evolving transnational political economy. This context is, on the one hand, marked by a radical decline in publicly available funding for central infrastructure needs - a decline recently aggravated by the draw of these funds from seriously undercapitalised banks involved in CDOs and other mortgage securitization instruments. On the other hand, this context is undergoing dramatic transformations with regard to its longstanding forms of political-legal regulation and market governance. As domestic welfare states are continuing to struggle with the aftermath and development prospects of privatisation and deregulation politics since the late 1970s, Western nations have meanwhile been active in shaping the emerging economies in the East and the South. The Development Agenda as pursued by the World Bank, gives an impressive testimony of the changing focus of its policies. ${ }^{83}$

From Individuals to Organizations to Networks? From Industrial Captains to Managerial Revolutionaries to the 'End' or 'Future' of Management? While many might agree, in theory and practice, that the successful operation of business of such highly volatile and risky, transnational markets continues to depend crucially on the persons behind the wheel, the modes of management are a matter of deep concern. ${ }^{84}$ At the same time, organizational sociologists and management theorists are pointing to the amorphous status of knowledge as a subject of scientific assessment and strategic exploitation: as knowledge begins to both transform and constantly reshape the global economy, the need arises for a sophisticated conceptual apparatus to assess this development. Needed are economics of knowledge ${ }^{85}$ as well as a theory of knowledge management that does not isolate business knowledge from questions of governance under conditions of uncertainty. ${ }^{86}$

\footnotetext{
${ }^{83}$ See, most recently, the World Bank Report: “Building Knowledge Economies” (2007), available at: http://siteresources.worldbank.org/KFDLP/Resources/4611971199907090464/BuildingKEbook.pdf

${ }^{84}$ G. Hamel, The Future of Management (with Bill Breen) (Harvard Business School Press, 2008), ch. I

${ }^{85}$ See D. Foray, The Economics of Knowledge [Paris: L'économie de la connaissance, 2000] (MIT Press, 2004)

${ }^{86} \mathrm{H}$. Willke, Systemisches Wissensmanagement, 2nd ed. (Lucius \& Lucius, 2001), at 6566; H. Willke, Smart Governance. Governing the Global Knowledge Society (Campus, 2007), ch. 3; regarding the distinction between risk and uncertainty, see already F. H.
} 
As global companies struggle to maintain their position in the market, the need to transnationalize management becomes crucially felt. With the biggest U.S. multinationals either still being 95 percent run by Americans and/or losing its trained and groomed foreigners to aggressively poaching emerging markets firms, the issues surrounding a volatile 'market for management' tend to eclipse the important questions regarding the transformation of management today. What does management need to know? How is that information generated, processed and utilized? How is that information turned into quality knowledge that informs corporate management today? How have the issues arising from a transformation of global markets identified above - first, the arrival of the emerging economies' actors on the scene and, second, the erosion of financial markets and the need to revisit the foundations of the much-hailed financialisation of corporate governance - begun to inform the scope of management responsibility?

Against this background, we must assess the emerging challenges to our traditional concepts of a company's responsibilities from a different angle. Corporate Social Responsibility [CSR] is today on the agenda of business leaders, policy makers and activists because it relates to questions of regulating corporate behaviour in a time where it has become a formidable challenge to identify what it is that a company does - admittedly a necessary prerequisite for any proposal of how companies should be regulated, to whom they owe which kind of responsibilities. Where companies are invested in domestic and transnational infrastructure provision projects pertaining to telecommunications, road construction, health care and old age care provision, energy services and urban development, among others, their identification as 'private' actors seems increasingly inadequate. There is certainly much more to that: the distinction between public and private has its roots in the liberal theory of contract law, that has for the longest time been drawing a line between an allegedly 'private' business agreement between two parties and a publicly enacted statute setting forth an enforceable set of rights and obligations. ${ }^{87}$

Knight, Risk, Uncertainty and Profit [unabridged republication of the 1957 ed. of the orig. 1921 ed.] (Dover Publications, Inc., 1921), 197.

${ }^{87}$ P. Zumbansen, 'The Law of Society: Governance Through Contract', (2007) 14 Ind. J. Glob. Leg. Stud. 191-233 [available at http://ssrn.com/abstract=988610] 
Of course, we know that even such a distinction can only hold where we fail to recognize that allegedly private agreements are embedded in a legally constructed system of rights allocation. ${ }^{88}$ The same holds true for our assessment of the corporation: if we look beyond the business corporation as an economic actor, we recognize that it is at home in two worlds: besides its emergence as an economic entity, its other nature is legal. ${ }^{89}$ Here, we see that a company exists by grace of the law that called it into being. This observation is an important starting point for any assessment of a company's responsibilities. Recognizing that a company is a legal construct, it becomes possible to ask and to answer questions regarding its nature, goals, and eventual limitations with respect to its double-nature.

But, it can be said that the continuing contestation of the business corporation's 'responsibilities' stems from the insight that the recognition of the legal nature of the firm does not resolve the normative questions arising out of the reality of the firm. The challenge facing all attempts at designing a comprehensive and effective CSR strategy today results from the fact that neither of these reconstructions offers much of a guidance here: the myriad contexts and markets in which companies operate today, the host of different societal functions, domestically and transnationally, which are driven deeply by the powerful transformations of today's Western societies, constitute a dramatically changed environment for business corporations. In the second half of the $20^{\text {th }}$ century, we had only slowly begun to conceptualise the changing governance forms for corporate entities as companies began to assume an ever-growing amount of formerly public functions. In many ways, the experiences of corporate governance reform were still very much embedded in a domestic, nation-

${ }^{88}$ M. R. Cohen, 'The Basis of Contract', (1932) 46 Harv. L. Rev. 553-592. And yet, the identification of a contract as a 'private arrangement' continues to illustrate the liberal core of Western legal order, which recognizes the individual's freedom of engaging in her private affairs, where and as long as this exercise of freedom does not infringe the rights of other members of society. The price to pay for such a theory of contract is of course the denial of any valid foundation to the distinction between public and private in the first place. The Realist critique, then, only points out what has forever been the basic architecture of the Western positivist legal order.

${ }^{89}$ J. Dewey, 'The Historic Background of Corporate Legal Personality', (1926) 35 Yale L. J. 655-673; C. Perrow, Organizing America. Wealth, Power, and the Origins of Corporate Capitalism (Princeton University Press, 2002), 22-47 
state framework of market regulation. Even with a dramatic rise of privatisation of virtually all sectors of public function, corporate regulation was still conceived of as occurring within a constellation made up of company, taxation and securities regulation on the one hand, and social welfare and labour/employment regulation on the other. With the winds of globalisation blowing hard and cold over the last few decades, the nationstate has increasingly lost its pivotal role as market regulator. As firms began spanning their activities across the globe, the state has been at odds in effectively governing this development. ${ }^{90}$ On the other side, from the perspective of many emerging market governments, it is their insatiable infrastructure needs that companies are lining up to satisfy. Companies such as CISCO and GM are offering governments a comprehensive infrastructure development program, along with the promise of themselves building some or even all of it. ${ }^{91}$ Meanwhile, the firm itself has been the site of true organizational innovation. As companies such as IBM are promoting the concept of the 'globally integrated enterprise', we are seeing the 'network society', in action. Moving jobs and capacities, human and financial, around the globe, according to identified needs and promises of growth, GIEs today assume myriad organizational forms, that fundamentally challenge concepts of legal regulation.

All these changes occur without or outside of the law, it appears, as it is no longer clear whether the self-governing normative regimes that structure global corporate activity are attached to a particular state. It is against this background, that we have to reconsider a conceptual approach that associates legal and political regulation with the state, while continuing to

${ }^{90}$ See D. Patterson/A. Afilalo, The New Global Trading Order. The Evolving State and the Future of Trade (Cambridge University Press, 2008), chs 1 and 2

91 The ECONOMIST, supra, at 13. For example, GE in 2006 signed an memorandum of understanding with China's National Development and Reform Commission geared towards collaborating on meeting some 200 second tier Chinese cities' need of electric and physical infrastructure - cities with a minimum $1 \mathrm{~m}$ population each. In the context of the company's engagement in Vietnam, with 'huge problems facing the country in water, oil, energy, aviation, rail and finance', the GE president met with three Vietnamese leaders who had priorly participated in GE's leadership program in the U.S., a coincidence the company described as a 'transfer a lot of learnings between us and we end up friends for life.”

${ }^{92}$ M. Castells, The Rise of the Network Society, The Information Age: Economy, Society and Culture, Vol. I. (2nd ed., 2000) (Blackwell, 1996) 
position the corporation in an ambiguously private sphere of selfregulation.

\section{B. The Corporation as State: - Corporate Social RESPONSIBILITY IN THE KNOWLEDGE SOCIETY}

In the knowledge society, the main protagonists are the post-modern state and the business corporation. Both actors occupy a central and yet highly ambivalent place within an increasingly complex, transnational regulatory space. The parallel observations on the state and the corporation are inspiring a historical-theoretical inquiry into the trajectories that sociologists have been tracing from the late $18^{\text {th }}$ century into the present with regard to the notions, concepts and understandings of 'society'. The idea of society here functions as a backdrop for a host of contentions as to the nature and goals of political, legal, state (societal) order. Emerging with the $19^{\text {th }}$ century, such ordering paradigms provided for an increasingly eminent role of the 'state' within the architectural imagination. Today, in light of the state's changing role in the growingly interconnected, transnational regulatory landscape, the very idea of 'society' begins to forcefully contest a number of the state's formerly held institutional and normative claims.

Any attempt to unpack the concept of society and, with it, of market, occurs against the background of far-reaching transformations of statemarket relations in the second half of the $20^{\text {th }}$ century. The impact of these transformations are reflected in the privatization and post-privatization debates from the late 1970s to the early to mid-1990s after the Fall of the Berlin Wall that were oriented towards a powerful reassertion of liberal ideas of freedom, which went hand in hand with a dramatically reduced influence of the state. Such conceptualizations occurred alongside an ever further reaching degree of privatization and outsourcing of public services, which in turn placed enormous pressure on traditional legal instruments including concepts of the administrative act and contract. ${ }^{93}$

${ }^{93}$ W. Hoffmann-Riem, 'Tendenzen in der Verwaltungsrechtsentwicklung', (1997) 50 DÖV 433-442 
With a dramatic reconfiguration of public and private governance modes at the end of the $20^{\text {th }}$ century Western Welfare State arises an urgent need to reassess the foundations on which our concepts of legal governance have come to rest. ${ }^{94}$ The case of the business corporation, studied through the paradigm of the transnational knowledge society, promises to offer rich insights into the foundations and directions of these ongoing changes precisely because the traditionally privately conceived firm has been assuming such a central place in the transformation of society from public to private ordering. Whereas public governance at the outset of the $21^{\text {st }}$ century is being described today by formulas ranging from the 'enabling' or 'moderating state' to the "risk", or "knowledge society", modern corporate governance in many ways resembles this fundamental concern with the transformation of regulation. The defining mark of contemporary governance is its radical dependency on dispersed, fragmented societal knowledge. As political scientists, sociologists and legal scholars alike are engaging in a theoretical-historical assessment of the regulatory prospects after the decline of the Western Welfare State, they question what might succeed the state as a central reference point within a decentralized knowledge society.

A parallel challenge can be discerned with regard to the large business corporation, which has in many ways been assuming formerly public functions. No wonder, then, that the debate among corporate lawyers, activists, philosophers and social scientists over 'corporate social responsibility' [CSR] continues with no end in sight. ${ }^{95}$ Seen through the sociological lens of the knowledge society, CSR functions as a powerful magnifying glass through which we gain a clearer view not only on the wide-ranging concerns over management power in today's large corporations, but also on the parallels between the information and knowledge generation and administration challenges in both firms and contemporary governments. Succeeding an early $20^{\text {th }}$ century pluralist formulation of corporate conflicts that focused on the opposed interests of owners, employees and creditors within and around the business

94 With more detail: P. Zumbansen, 'Law After the Welfare State: Formalism, Functionalism and the Ironic Turn of Reflexive Law', (2008) 56 Am. J. Comp. L. 769-805

95 A powerful assessment of the corporation's assumption of the governance of citizenship is now offered by A. Crane/D. Matten/J. Moon, Corporations and Citizenship (Cambridge University Press, 2008), 50-87. 
corporation, an adequate conceptualization of CSR must begin to incorporate and internalize a radically more complex perspective on corporate governance. A thus more promising concept of CSR would thus suggest focusing on the different fields in which the company exerts itself. Such 'fields' may be identified through a regulatory lens ${ }^{96}$ or by identifying the 'things companies do' and 'why'. ${ }^{97}$ Based on an approach that seeks to integrate a sociological theory of society into the identification of the content and scope of the corporation's various responsibilities one might gain a better understanding of the nature of the corporation in that society.

Where traditional CSR concepts are often conceptualized in opposition against something that had been taken as the dominant and exclusive definition of the corporation (as profit maximizer) ${ }^{98}$, the here-proposed CSR approach is likely to provide an analysis of the way in which the corporation's economic performance, embedded in a more comprehensive assessment of the different functions the corporation assumes in society, forms part of the corporation's role in different social systems. As the corporation passes through the three paradigms, CSR in turn can no longer be understood as the counter program or, add-on to corporate governance $^{99}$, but must be seen as a lens through which to study the reconceptualization of corporate governance. From this perspective, the parallels between the early $21^{\text {st }}$ century state and the contemporary

${ }^{96}$ C. A. Williams, 'The Securities and Exchange Commission and Corporate Social Transparency', (1999) 112 Harv. L. Rev. 1197-1311; C. Williams/J. Conley, 'Is there an Emerging Fiduciary Duty to Consider Human Rights?' (2005) 74 U. Cincinnati L. Rev. 75-104; A. Dhir, 'Realigning the Corporate Building Blocks: Shareholder Proposals as a Vehicle for Achieving Corporate Social and Human Rights Accountability', (2006) 43 American Business Law Journal 365

${ }^{97}$ R. Aguilera/D. Rupp/C. A. Williams/J. Ganapathi, 'Putting the S Back in Corporate Social Responsibility: a Multi-Level Theory of Social Change in Organizations', (2004) 32 Academy of Management Review 836-863 [http://papers.ssrn.com/sol3/papers.cfm?abstract_id=567842]

${ }^{98}$ H. J. Glasbeek, 'The Corporate Social Responsibility Movement - The Latest in Maginot Lines to Save Capitalism', (1988) 11 Dalhousie L. J. 363-402

${ }^{99}$ See the critique by R. B. Reich, 'The Case Against Corporate Social Responsibility', (2008) UC Berkeley Goldman School of Public Policy Working Paper 08-003 http://ssrn.com/abstract=1213129. 
business corporation can help us understand the challenges that face both concepts in light of a complex, transnational knowledge society. The state in a functionally differentiated society has been described as the evolving institutionalization of the political system, which is merely one of several communications taking place in society. In turn, the corporation can be seen as being determined by the processes of functional differentiation of the economic system. This observation has been used in fact to sketch a radically expanded, more complex concept of the corporation than would have been possible under either the industrial-organizational or the financial paradigm. ${ }^{100}$ As the contours of the knowledge society and the actors, actants ${ }^{101}$ and networks associated with it become increasingly clear, the concept of the corporation evolves at breathtaking speed and with daunting complexity. Mirroring the blurring and erosion of its physical and legal boundaries, the corporation's nature is once again seemingly beyond grasp. The persistently growing sophistication of organizational and management theory allows us at least to better appreciate the task. Building on theories of the innovative firm ${ }^{102}$ in the context of an expanding understanding of the knowledge society is likely to provide us with a more adequate concept of the corporation today.

What is the Knowledge Society? Its defining marks can be seen in the overriding, crucial role, which is played by the generation, dissemination and application of knowledge - as opposed to mere information. Following a distinction introduced by Joel Mokyr, the difference between propositional knowledge (describing existing constellations) and prescriptive knowledge (applied with the goal of shaping outcomes) ${ }^{103}$

\footnotetext{
${ }^{100}$ G. Teubner, 'Enterprise Corporatism: New Industrial Policy and the 'Essence' of the Legal Person', (1988) 36 Am. J. Comp. L. 130-155; G. Teubner, 'The Invisible Cupola: From Causal to Collective Attribution in Ecological Liability', in G. Teubner,L. Farmer and D. Murphy (eds.), Environmental Law and Ecological Responsibility: The Concept and Practice of Ecological Self-Organization (Wiley, 1994)

${ }^{101}$ B. Latour, Reassembling the Social. An Introduction to Actor-Network Theory (Oxford University Press, 2005)

${ }^{102}$ W. Lazonick, 'The Innovative Firm', in J. Fagerberg (eds.), Oxford Handbook of Innovation (Oxford University Press, 2005); W. Lazonick, 'Varieties of Capitalism and Innovative Enterprise', (2007) 24 Comparative Social Research 21-69

${ }^{103}$ J. Mokyr, 'The Knowledge Society: Theoretical and Historical Underpinnings', (2005) faculty.wcas.northwestern.edu/ jmokyr/Unitednations.PDF , 2
} 
matters because while the basis of the former grows, the latter is part of a much more complex institutional framework. Knowledge gathered, developed and assessed for future-oriented development becomes embedded in a dramatically transformed environment, governed - above all - by conditions of complexity and uncertainty. ${ }^{104}$ To the degree that it has been become increasingly difficult to clearly associate a particular legislative, regulatory initiative with one or the other political partisan camp, former invocations or contestations of redistribution in the name of 'social justice' or 'freedom' ring today strangely faint. In a fast evolving context of a globally merging market and knowledge society a reconceptualization of public and private forms of governance becomes necessary, but the orientation points are hard to identify. In contrast to the depictions rendered by Weber or Polanyi, we are urged to understand the boundaries between politics and society as having been artificially drawn with reference to historically evolved patterns of institutional development and depicted as political institutions on the one hand, market institutions on the other: patterns that have meanwhile come to seem extremely blurry, as both political and 'private' actors such as non-governmental organizations, corporations, collectives and individuals operate under conditions of extreme uncertainty can hardly be depicted through references to either 'public' or 'private', 'political' or 'market'. 105

Governments and corporations alike are dependent on increasingly fragmented, societal knowledge, which leads to an important reconfiguration of the relations between the different actors within and outside of their organizational boundaries. ${ }^{106}$ As sociologists describe the state as the emblem of the political system in a functionally differentiated

104 U. Beck, 'From Industrial Society to Risk Society: Questions of Survival, Social Structure and Ecological Enlightenment', (1992) 9 Theory, Culture \& Society 97-123; M. Power, 'From Risk Society to Audit Society', (1997) 3 Soziale Systeme 3-21 [http://www.soziale-systeme.ch/leseproben/power.htm]

105 See most recently H. Willke, Smart Governance. Governing the Global Knowledge Society (Campus, 2007).

106 D. Pestre, 'Science, Society and Politics. Knowledge Societies from Historical Perspective', (2007) Report to the Science, Economy and Society Directorate at the European Commission http://ec.europa.eu/research/sciencesociety/document_library/pdf_06/historical-perspectives_en.pdf, 911 
society without centre or pinnacle (Luhmann), we see this society emerging as a society that is complex and marked by 'a multiplicity of independent and parallel regulations'. ${ }^{107}$ The state, in its dependence on constantly updated information, is at the same time implicated in the production of that very information by creating rules and facilitating institutional growth for knowledge production and dissemination ${ }^{108}$, which raises again far-reaching legitimacy problems, that democratic and legal theory only insufficiently have been trying to address through enhanced 'participation' models. ${ }^{109}$

Meanwhile, corporations, like other societal actors involved in market identification, creation and consolidation, in investment and redistribution activities as well as in $R \& D$ and 'knowledge management' ${ }^{110}$, face pressing governance challenges that in many ways mirror those of contemporary political governing bodies. ${ }^{111}$ The dependence of

107 Id., at 9

${ }^{108}$ K.-H. Ladeur, Der Staat gegen die Gesellschaft (Mohr Siebeck, 2006)

${ }^{109}$ Pestre, supra, 10, expressing deep skepticism about the viability of such approaches in light of the high-level scientific knowledge that is today used to support political decision-making; with regard to an emphasis on 'participation' as a cure for the legitimacy problem of contemporary domestic and transnational decision-making bodies, see critically N. Krisch/B. Kingsbury/R. B. Stewart, 'The Emergence of Global Administrative Law', (2005) 68 Law and Contemporary Problems 15, and C. Harlow, 'Global Administrative Law: The Quest for Principles and Values', (2006) 17 Eur. J. Int'l L. 187-214

110 O. Bouba-Olga, L'économie de l'entreprise (Éditions du Seuil, 2003), 170-173; D. Foray, The Economics of Knowledge [Paris: L'économie de la connaissance, 2000] (MIT Press, 2004), 217; D. Baecker, Studien zur nächsten Gesellschaft (Suhrkamp, 2008), 22: "The innovative corporations of the coming society will have bid the nervous selfconfidence farewell, in accordance with which they understood their fate to be exclusively determined by the economy, meaning that it would be sealed on markets, where corporations compete with each other for the demands of affluent consumers. The corporation's fate does, indeed, decide itself here, but, at the same time, it decides itself in the laboratories of science, in the praying halls of churches, in court rooms, in the backrooms of politics and in the editing offices of newspapers, television broadcasters and internet hosts.” [Translated by P.Z.]

${ }^{111}$ P. Zumbansen, 'The Conundrum of Corporate Social Responsibility: Remarks on the Changing Nature of Firms and States', in R. Bratspies and R. Miller (eds.), Transboundary Harm: Lessons from the Trail Smelter Arbitration (Cambridge University Press, 2006) 
management on expert knowledge, which is generated and communicated both in- and outside of the firm, has grown in correlation with the expanding reach of business activities and their impact. As in other areas of law, the notion of the 'expert' has itself come under increased scrutiny. In corporate law, certainly, long-standing attempts to give workers a voice have since begun to inform important demands for more diversity in the boardroom, in particular with regard to gender and race. ${ }^{112}$ With governments and corporations as knowledge actors, producers and consumers, the pressure on law to facilitate and to enable these processes has exponentially grown. Not adequately captured as being situated in an either exclusively public or private sphere, 'political', 'private', corporate actors are both authors and receivers of the rules that govern their behaviour. While this new view on the embeddedness of societal activity in a decentralized, de-territorialized and de-hierarchized knowledge society suggests a paradigmatic move beyond distinctions based on institutional manifestation (“state”/“market”) or political, normative demarcation ("public"/ "private") ${ }^{113}$, the place to ask the original CSR questions becomes increasingly elusive. ${ }^{114}$ These questions must turn to 'culture ${ }^{115}$ and to the corporation's place and nature in the 'coming

112 See A.A. Dhir, 'Towards a Race and Gender-Conscious Conception of the Firm: Canadian Corporate Governance, Law and Diversity', CLPE Research Paper 2009, available at www.comparativeresearch.net

113 See the contributions to H. Kitschelt/P. Lange/G. Marks/J. D. Stephens (eds.), Continuity and Change in Contemporary Capitalism (Cambridge University Press, 1999); J. R. Hollingsworth/R. Boyer (eds.), Contemporary Capitalism. The Embeddedness of Institutions (Cambridge University Press, 1997)

114 J. Mokyr, 'The Knowledge Society: Theoretical and Historical Underpinnings', (2005) faculty.wcas.northwestern.edu/ jmokyr/Unitednations.PDF ; H. Willke, Smart Governance. Governing the Global Knowledge Society (Campus, 2007), 35, describing the need to translate institutions governing 'normative decision-making', involving assertions that decisions about the future are based on norms and normative considerations, into institutions facilitating 'cognitive' decision-making based on knowledge.

115 J. M. Conley/C. A. Williams, 'The Corporate Social Responsibility Movement as an Ethnographic Problem', (2008) Working Paper http://papers.ssrn.com/sol3/papers.cfm?abstract_id=1285631; see also Aaron Dhir's Research Project at Osgoode Hall Law School's CLPE Comparative Research in Law \& Political Economy Network on 'Canadian Corporate Governance, Law and Racial Diversity'

[http://www.comparativeresearch.net/jsp/projectdetail.jsp?projectid=1000000011] 
society ${ }^{\text {,16 }}$ just as the inquiry into the nature of the state must reach beyond the narrow choice between the state's waning or 'returning'. ${ }^{117}$ This is the challenge of corporate governance in the knowledge society.

${ }^{116}$ D. Baecker, Studien zur nächsten Gesellschaft (Suhrkamp, 2008)

117 S. Strange, The Retreat of the State (Cambridge University Press, 1996); A. Harmes, The Return of the State (Douglas \& McIntyre, 2004) 